\title{
DOS INSTITUTOS JURÍDICOS DA POSSE E DA PROPRIEDADE PRIVADA E A REGULARIZAÇÃO DO PARCELAMENTO E LOTEAMENTO IRREGULAR OU CLANDESTINO DO SOLO COM BASE NO PROVIMENTO № 21/2011
}

\author{
Andressa Beschorner Gonsalves ${ }^{1}$ \\ Patrícia Outeiral de Oliveira ${ }^{2}$
}

RESUMO: $O$ presente artigo analisa a aplicabilidade do Provimento $\mathrm{n}^{\circ}$ 21/2011 - CGJ/RS (Projeto More Legal IV) na regularização de parcelamento e loteamentos irregulares ou clandestinos. Para tanto, além das abordagens acerca do instituto em estudo, trazendo o seu histórico e procedimento, serão analisados os instrumentos que são os princípios fundadores do Projeto More Legal, sendo eles: a posse e sua função social, a regularização fundiária por meio de políticas públicas e o Parcelamento do Solo Urbano pela Lei $\mathrm{n}^{\circ}$ $6.766 / 79$. Será realizada uma abordagem histórica quanto ao instituto da posse, bem como a necessidade de se reconhecer a função social da posse para sua proteção no mundo jurídico, eis que a função social da posse está intimamente ligada ao princípio da dignidade humana. Quanto às políticas públicas, observar-se-á a sua ineficiência para concretizar o direito posto pela legislação, visto que as políticas públicas atualmente existentes não foram capazes de resolver os inúmeros casos de loteamentos clandestinos ou irregulares, de modo a necessitar de intervenção jurisdicional, tal como o More Legal, para atender esses direitos sociais emanados. Ao final do estudo dos artigos fundamentais do Provimento no 21/2011 - CGJ/RS, verificar-se-á a aplicação e efetividade deste instrumento como meio de regularização de parcelamentos e loteamentos irregulares ou clandestinos no Rio Grande do Sul.

Palavras-chave: Posse; Função Social; Regularização Fundiária; More Legal; Provimento no 21/2011 - CGJ/RS.

\section{INTRODUÇÃO}

Os institutos da posse e da propriedade aparecem em constante relação entre os homens, onde se permitem distinções curtas que afirmam que a posse é um fato natural e a propriedade uma criação da lei. ${ }^{3}$ Ainda que tenhamos

\footnotetext{
${ }^{1}$ Advogada e Especialista em Direito Imobiliário.

2 Professora e Coordenadora do IPA-Porto Alegre. Mestre em Direito. Doutoranda em Qualidade ambiental na FEEVALE.

${ }^{3}$ REZENDE, Astolpho. A posse e sua proteção. Rio de Janeiro, 2000. Editora Lejus, 2. ed. p. 1 .
}

DIREITO, CULTURA E CIDADANIA

Osório, v. 7, n. 1, 2017

DOI 10.26547/2236.3734.2017.1.183 
estabelecido meios jurídicos de diferenciação entre posse e propriedade ao longo dos séculos, nós, como sociedade, ainda mantivemos a cultura da propriedade automaticamente relacionada à posse.

Fato inegável é que a posse - estado de fato -, antecedeu a propriedade estado de direito -, na apreensão e utilização das coisas do mundo externo para a satisfação das necessidades do homem. Atualmente, quando falamos em propriedade, nos referimos a um instituto amplo e, por vezes, carente de muitas iniciativas do Poder Público para sua regulamentação e proteção. Embora as legislações vigentes reconheçam a propriedade como um direito fundamental ao ser humano e inerente a sua existência, estabelecendo meios para sua garantia e proteção nas relações jurídicas, ainda existem muitos imóveis ilegais, ou seja, carentes do prévio registro junto ao Ofício de Registro de Imóveis, não permitindo o seu possuidor (que se identifica como proprietário) gozar dos seus mais amplos poderes, tais como usar, fruir e dispor.

Nesse contexto, ao encontrar-se na situação de possuidor do imóvel, o cidadão poderá ter muitos outros direitos fundamentais e sociais - inerentes a sobrevivência sadia - sonegados, entre eles a dignidade da pessoa humana, visto que a irregularidade do imóvel pode gerar a falta de um saneamento adequado, de energia elétrica e distribuição adequada de água, por exemplo.

Deste modo, restará demonstrada a necessidade do reconhecimento do instituto da posse no nosso ordenamento jurídico, atrelada a sua função social, como instrumento para alcançar o direito de propriedade a muitas famílias que estão marginalizadas por não se enquadrem nas escassas leis de regularização fundiária. Contudo, veremos que, ao mesmo tempo, necessitamos de políticas públicas de regularização fundiária capazes de promover tal direito. ${ }^{4} \mathrm{E}$, não obstante, as que atualmente existem não conseguiram acompanhar efetivamente as necessidades sociais, o que acabou por demandar uma "intromissão" do Poder Judiciário, no intuito de solver

\footnotetext{
4 WOLF, Guilherme Eidelwein. A regularização fundiária urbana no Brasil e seus instrumentos de alcance. Notas introdutórias acerca do direito fundamental à moradia frente às políticas públicas de regularização fundiária. P. 19 de 86. Disponível em: <http://www.jurisway.org.br/v2/dhall.asp?iddh= 8957>. Acesso em: 29 jun. 2017.
} 
problemas relacionados ao alcance de direitos sociais e fundamentais da sociedade brasileira.

Sob essa ótica, analisaremos a Lei Federal n 6.766/79, a qual tem por escopo o ordenamento físico do espaço destinado à habitação. Contudo, mesmo que essa estabeleça os conceitos basilares da regularização fundiária, ainda se faz mister a existência de um instrumento jurídico capaz de regularizar loteamentos irregulares ou clandestinos e seus parcelamentos, fracionamentos ou desmembramentos para, então, tornar efetivo o direito de propriedade daqueles que dele carecem. E o Projeto More Legal, oriundo da Corregedoria Geral de Justiça do Rio Grande do Sul, que trata da regularização dos parcelamentos e loteamentos irregulares ou clandestinos de terras, urbanas ou urbanizadas, como se verificará ao longo do presente estudo, se apresenta como instrumento válido para tanto.

Com base nessas considerações iniciais, o presente estudo tentará demonstrar a origem histórica que levou a elaboração do Projeto More Legal no Rio Grande do Sul, o qual trata da regularização dos parcelamentos irregulares ou clandestinos de terras, ditas urbanas ou urbanizadas, no intuito de avaliar a sua efetividade como método de regularização fundiária para alcance do direito de propriedade.

\section{DA POSSE: EVOLUÇÃO DA CONCEPÇÃO DA POSSE E SEU AMPARO JURÍDICO NO TEMPO}

Ao longo dos tempos, um trabalho árduo para os doutrinadores é encontrar a natureza jurídica da posse, determinando se a mesma é uma realidade fática ou uma realidade de direito. ${ }^{5}$

Conceitualmente falando, Lafayette Pereira ministra que "[...] a posse é caracterizada por uma fruição entre a pessoa e a coisa, pela qual a pessoa

\footnotetext{
${ }^{5}$ ALBUQUERQUE, Ana Rita Vieira. Da Função Social da Posse e sua Consequência Frente à Situação Proprietária. Rio de Janeiro: Editora Lumen Juris, 2002. p. 177. 
está determinada a possuir a coisa e apropriar-se dos frutos que ela produzir, comportando-se intencionalmente como titular de direito sobre a coisa". 6

Tal entendimento se faz necessário no presente estudo, uma vez que, ao falarmos de aquisição da propriedade por meio de uma decisão judicial, estamos tratando do reconhecimento da posse dotada de função social, a qual dá sentido ao princípio da dignidade da pessoa humana e ao direito de moradia.

\subsection{Origem da posse através das teorias}

Não há um entendimento uníssono na doutrina sobre a origem da posse como um estado de fato legalmente protegido. Contudo, a certeza de o instituto posse - tutelado pela lei - se originou nos fenômenos jurídicos que iniciaram a organização romana é corrente dominante, pois fora Roma que organizou o direito, com uma extensa projeção sobre o futuro. ${ }^{7}$

Em relação a concepção da posse pelas antigas escolas, a posse presume a ideia de uma situação de fato, em que uma pessoa, independentemente de ser ou de não ser proprietária, exerce sobre uma coisa poderes ostensivos, conservando-a e defendendo-a, tal como na propriedade. ${ }^{8}$

Desta forma, é possível a visualização de dois elementos que se conjugam na configuração de uma situação possessória: um elemento material (atos materiais exercidos sobre a coisa) e um elemento psicológico (intenção de se comportar como titular do direito real). Assim, segundo Caio Mário, tais elementos se resumem como "uma coisa, e uma vontade, que sobre ela se exerce". 9

De acordo com a teoria subjetiva, defendida por Savigny, a posse se configura pela reunião dos elementos corpus e animus. O corpus corresponderia ao

\footnotetext{
${ }^{6}$ PEREIRA, Lafayette Rodrigues. Direito das coisas. Rio de Janeiro: Editora Rio, 1977. p.39.

${ }^{7}$ REZENDE, Astolpho. A posse e sua proteção. Rio de Janeiro, 2000. Editora Lejus, 2. ed. P. 1

8 PEREIRA, Caio Mário da Silva. Instituições de direito civil. Rio de Janeiro, Forense: Brasília, 1974. p. 20.

${ }^{9}$ PEREIRA, Caio Mário da Silva. Instituições de Direito Civil. Rio de Janeiro: Forense, 1995. P.15
} 
poder físico sobre a coisa, articulado ao animus, que é a intenção de ter a coisa como própria. ${ }^{10}$

Já a teria objetiva, sustentada por lhering, sustenta a existência apenas do elemento material ${ }^{11}$, visto que esse estaria caracterizado tão somente na vontade de elemento. Necessário apenas a aparência de dono, não havendo necessidade de pesquisar sua intenção.

Ressalte-se que, a teoria de Ihering, adotada pelo nosso Código Civil vigente, ao formular indícios históricos da anterioridade da posse em relação à propriedade, preocupou-se em justificar tal anterioridade, de forma a evidenciar a superioridade da propriedade em relação à posse ${ }^{12}$, o que demonstra que, embora os normativos da época defendessem a posse, a mesma continha vícios que impediam o reconhecimento do direito real como um todo, o que acabava por prejudicar os possuidores, ainda que dotados de boa-fé.

Deste modo, podemos dizer que se trata a posse de "um instrumento para alcançar a verdadeira função social da propriedade, pois essa sem aquela não existe". ${ }^{13}$ Assim sendo, devemos visualizar a posse dotada de função social como o primeiro passo para a aquisição da propriedade, independente do instrumento jurídico de regularização fundiária utilizado para alcança-la.

\subsection{Função Social da Posse e da Propriedade}

É evidente que o instituto da posse é um instituto concebido independentemente da propriedade, capaz de responder às contingências sociais, uma vez que evidente em seu conceito um elemento externo, qual seja: a consciência social - o que lhe pressupõe uma função social imanente.

A Constituição Federal, desde os seus primordes, elenca como direitos fundamentais os direitos sociais, as políticas públicas de habitação, de saúde,

${ }^{10}$ CHALHUB, Melhim Namem. Curso de Direito Civil: direitos reais. Rio de Janeiro: Forense, 2003. p. 17.

${ }^{11}$ Idem. p. 17-18.

12 ALBUQUERQUE, Ana Rita Vieira. Da Função Social da Posse e sua Consequência Frente à Situação Proprietária. Rio de Janeiro: Editora Lumen Juris, 2002. p. 61.

${ }^{13}$ MIRANDA, Pontes de. Tratado de Direito Privado - Tomo 5. Editora Bookseller. Ed. 1.p. 117. 
de segurança social, entre outras. Assim, uma vez que a posse é fruto do fato social em si, não pode a mesma deixar de ser amparada pela Constituição Federal, ainda que não explicitamente, visto que representa verdadeira emanação da personalidade humana, comprometida com a efetividade do princípio da dignidade da pessoa humana. ${ }^{14}$

Desta forma, podemos dizer que a função social da posse advém da necessidade social que imana do instituto da posse, vez que há necessidade da terra para o trabalho, para a moradia, para a segurança familiar, ou seja, para que se cumpra o conceito de dignidade da pessoa humana, de cidadania, de direito de proteção à personalidade e a própria vida. Somente através da utilização social da posse veremos a redução da desigualdade social e a incrementação da justiça distributiva. ${ }^{15}$

Em relação a propriedade, sabemos que Constituição Federal Brasileira de 1988 resguarda o direito de propriedade. Contudo, qualquer propriedade que queira estar amparada pela proteção constitucional deverá atender a função social estabelecida no texto de lei constitucional, o qual determina que "[...] a propriedade urbana cumpre sua função social quando atende às exigências fundamentais de ordenação da cidade expressas no plano diretor". ${ }^{16}$

Nesse ínterim, tal como na propriedade, a função social da posse não significa uma limitação ao direito, mas sim uma exteriorização do conteúdo que lhe é imanente, "[...] permitindo uma visão mais ampla do instituto, de sua utilidade social e de sua autonomia diante de outros institutos jurídicos". ${ }^{17}$ Atingindo sua função social, podemos obter uma melhor posse, que coaduna com a nossa identidade social e cultural e que mais se assemelha a propriedade de fato.

A posse útil - dotada de função social - e direta do bem traz consigo valores sociais inexplícitos, tais como o valor à vida, à moradia, à saúde, à

${ }^{14}$ ALBUQUERQUE, Ana Rita Vieira. Da Função Social da Posse e sua Consequência Frente à Situação Proprietária. Rio de Janeiro: Editora Lumen Juris, 2002. p. 16

${ }^{15}$ Idem. p. 15.

${ }^{16}$ Art. 182. [...] $\S 2^{\circ}$ - A propriedade urbana cumpre sua função social quando atende às exigências fundamentais de ordenação da cidade expressas no plano diretor. BRASIL, Constituição da República Federativa do Brasil. Brasília, DF: Senado Federal, 1988.

17 ALBUQUERQUE, Ana Rita Vieira. Da Função Social da Posse e sua Consequência Frente à Situação Proprietária. Rio de Janeiro: Editora Lumen Juris, 2002. p. 12. 
igualdade e à justiça, de forma a manter o princípio da dignidade da pessoa humana como sustento do Estado democrático de direito.

A falta de uma disposição expressa sob a tutela da posse que exerce sua função social na Magna Carta não significa que a mesma não possa ser tutelada por analogia e pelos costumes e princípios gerais do direito. Albuquerque define que "[...] a omissão pressupõe a falta de uma norma específica a ser aplicada, mas não a ausência de critérios válidos para se decidir acerca de sua aplicação". ${ }^{18}$

Nesse compasso, a função social da posse é invocada como elemento capaz de atenuar as diferenças sociais. Enquanto houver situações que exponham o ser humano a precariedade e comprometam a dignidade humana, haverá motivos para que se defendam a positivação constitucional da função social da posse. De acordo com lhering, "a posse sem um proveito possível seria a mais inútil das coisas do mundo; seu valor consiste unicamente na função indicada: é um meio para alcançar um fim". ${ }^{19}$

Diante disso, importa saber que, quando nos referimos a posse exercida pelos possuidores que podem usufruir do Provimento no 21/2011 na busca da regularização da mesma como propriedade de direito, estamos nos referindo, principalmente, aos possuidores de uma posse justa (não lhe pesa a marca de defeito estabelecido no Código Civil, ou seja, não é violenta, clandestina ou precária) e de boa-fé (ignoram o fato de que a compra através de simples contrato particular não transfere a propriedade para si), independentemente da existência ou não de um título hábil. De maneira fundamental, os possuidores exercem não somente o domínio material e útil (sob o aspecto social) sobre a coisa, mas também o desejo incessante de possuir um direito real sobre o bem (ideia de que o bem imóvel é seu).

Ademais, no intuito de visualizar a importância do Provimento $n^{0}$ 21/2011 - CGJ/RS, é inerente o estudo das ações públicas voltadas para a regularização de posses/propriedades - dotadas de função social - à margem

\footnotetext{
18 Idem, p. 37.

19 IHERING, Rudolf von, 1818-1892. Teoria simplificada da posse. Tradutor Fernando Bragança. Belo Horizonte: Ed. Líder, 2004, p. 08.
}

\section{DIREITO, CULTURA E CIDADANIA}


da legislação, eis que somente assim é possível a visualização da ineficiência das políticas públicas e da legislação pertinente para fins de regularização fundiária.

\section{DA REGULARIZAÇÃO FUNDIÁRIA POR MEIO DE POLÍTICAS PÚBLICAS E DO PARCELAMENTO DO SOLO URBANO PELA LEI № 6.766/79}

O direito de propriedade e, consequentemente o direito de moradia atrelado à posse, como já expostos, estão incluídos no rol dos direitos fundamentais e sociais, ou direitos de segunda geração. Contudo, para que o mesmo se torne efetivo, segundo Guilherme Wolf ${ }^{20}$, são necessárias políticas públicas de regularização fundiária capazes de promover tal direito. Nesse aspecto, podemos definir a política pública, de um modo geral, como a atuação do Governo, consistente num conjunto de medidas articuladas, cujo escopo é dar impulso na máquina do governo para concretizar o direito posto pela legislação. ${ }^{21}$

No que tange a regularização fundiária, tem-se como um "[...] processo que visa garantir a segurança jurídica do uso do solo a quem de fato o ocupa, adequando-o urbanisticamente, [...] geralmente associado à moradia". ${ }^{22}$

Deste modo, com base nos conceitos colacionados, podemos concluir que, uma vez que a regularização fundiária advém principalmente de políticas públicas, esta é fundamentalmente de competência do Poder Executivo. Contudo, como pode o Provimento no 21/2011 tratar sobre formas de regularização fundiária, vez que esse é oriundo do nosso Poder Judiciário? No

20 WOLF, Guilherme Eidelwein. A regularização fundiária urbana no Brasil e seus instrumentos de alcance. Notas introdutórias acerca do direito fundamental à moradia frente às políticas públicas de regularização fundiária. P. 19 de 86. Disponível em: <http://www.jurisway.org.br/v2/ dhall.asp?iddh= 8957>. Acesso em: 10 jun. 2017.

${ }^{21} \mathrm{BUCCl}$, Maria Paula Dallari. $\mathrm{O}$ conceito de política pública em direito. Políticas Públicas: reflexões sobre o conceito jurídico. São Paulo: Saraiva, 2006. p. 52.

22 BALBIM, Renato. Avanços recentes no quadro normativo federal da regularização fundiária. In: Planejamento e políticas públicas, no 34. Jan-jun de 2010. Brasília: IPEA, 2010. E-book. Disponível em: <http://www.ipea.gov.br/ppp/index.php/PPP/article/viewFile/ 176/189>. p. 178. Acesso em: 10 jun. 2017. 
entender de Maria Paula Bucci ${ }^{23}$, a atuação judicial nas políticas públicas é um dos pontos mais polêmicos atualmente, uma vez que, segundo seu entendimento, essa seria imprópria. Contudo, como direito e garantia fundamental, a Constituição Federal de 1988, em seu art.5ำ, inciso XXXV, prevê que "a lei não excluirá da apreciação do Poder Judiciário lesão ou ameaça a direito". ${ }^{24}$

Dessa forma, Guilherme Wolf argumenta que "tendo a política pública expressado direitos, existe a possibilidade de submetê-la ao controle jurisdicional". ${ }^{25}$ Nesse contexto, a participação do judiciário frente aos problemas relacionados aos direitos sociais é crescente, sendo hoje uma válvula de escape para garantir a aplicabilidade de normativos emanados do executivo.

Quanto à indagação, Natalia Marra apresenta uma justificativa para a atuação do judiciário, cada vez mais significativa, no sistema de regularizações fundiárias: evolução. Nos seus dizeres, nosso "[...] ordenamento jurídico tem evoluído muito na matéria dos direitos humanos, direitos urbanísticos, direitos reais (posse e propriedade) e no acesso à moradia adequada [...]"26, algo que 0 sistema de políticas públicas não conseguiu acompanhar, ainda que existentes muitas regulamentações públicas sobre regularização fundiária.

Tal situação ocorre pelo fato de que qualquer política pública necessita do comprometimento de seus gestores. $\mathrm{E}$, inevitavelmente, quando tratamos do Poder Executivo, é mister lembrar que este está por trás de um jogo de interesses e afinidades políticas, o qual pode dificultar ou comprometer a implementação de instrumentos de reforma urbana, vez que diante dos novos

${ }^{23} \mathrm{BUCCl}$, Maria Paula Dallari. $\mathbf{O}$ conceito de política pública em direito. Políticas Públicas: reflexões sobre o conceito jurídico. São Paulo: Saraiva, 2006. p. 58.

${ }^{24}$ BRASIL, Constituição (1988). Constituição da República Federativa do Brasil. Brasília, DF: Senado Federal, 1988

25 WOLF, Guilherme Eidelwein. A regularização fundiária urbana no Brasil e seus instrumentos de alcance. Notas introdutórias acerca do direito fundamental à moradia frente às políticas públicas de regularização fundiária. P. 19 de 86. Disponível em: <http://www.jurisway.org.br/v2/dhall.asp?id_dh=8957>. Acesso em:10 jun. 2017.

${ }^{26}$ MARRA, Natalia Cardoso. Políticas públicas de habitação e a efetivação do direito social e fundamental à moradia. Publicado em 2010. Disponível em: <http://www.conpedi.org.br/manaus/ arquivos/anais/fortaleza/3309.pdf>. Acesso em:10 jun. 2017. 
anseios sociais, estes latejam por diretrizes capazes de abarcar a nova realidade social da população brasileira (crescimento desordenado, sem condições básicas de saneamento e infraestrutura).

$\mathrm{E}$, diante dessa problemática, buscando trazer um conceito amplo e moderno, de modo a abranger todas essas circunstâncias, que a Lei no $11.977 / 09^{27}$ conceituou, no caput do artigo 46, a atividade de regularização fundiária como um:

[...] conjunto de medidas jurídicas, urbanísticas, ambientais e sociais que visam à regularização de assentamentos irregulares e à titulação de seus ocupantes, de modo a garantir o direito social à moradia, 0 pleno desenvolvimento das funções sociais da propriedade urbana e o direito ao meio ambiente ecologicamente equilibrado.

Assim, por causa da ausência de uma política habitacional capaz de efetivar o direito de propriedade e moradia à população de baixa renda, visualizou-se um crescimento do mercado habitacional informal, o qual "[...] tem sido decisivo na configuração das cidades brasileiras nas últimas décadas". ${ }^{28} \mathrm{E}$ é nesse contexto que se assenta os parcelamentos irregulares e clandestinos aqui relacionados.

Deste modo, no intuito de modificar essa realidade, hoje se entende que deverá existir uma cooperação de Poderes e dos entes federativos para a efetividade do direito posto. Uma iniciativa do Governo Federal foi a publicação da Lei 6.766/79, a qual regula o parcelamento do solo no Brasil, de maneira a tentar evitar situações registrais irregulares quando do loteamento ou desmembramento de áreas.

Em relação ao parcelamento do solo, frise-se que este tem por finalidade substancial ordenar o espaço urbano destinado à habitação. Numa análise inicial da Lei ํo 6.766/79, depreende-se que, no seu artigo 1ํㅡ, parágrafo

27 BRASIL. Lei no 11.977, de 7 de julho de 2009. Disponível em: <http://www.planalto.gov.br/ccivil _03/_ato2007-2010/2009/lei/l11977.htm>. Acesso em: 10 jun. 2017.

28 D'OTTAVIANO, Maria Camila Loffredo; SILVA, Sérgio Luís Quaglia. Regularização fundiária no Brasil: velhas e novas questões. Brasília: IPEA, 2010. E-book. P. $202-$ 201/229. Disponível em: <http://www.ipea.gov.br/ppp/index.php/PPP/article/view/172/185>. Acesso em: 11 jun. 2017. 
único ${ }^{29}$, fica definido que os Estados, Distrito Federal e Municípios poderão estabelecer normas complementares à lei, de acordo com as suas necessidades no tocante à política urbana.

No artigo $2^{\circ}$, a lei determina que o parcelamento do solo será mediante desmembramento ou loteamento, de acordo com as legislações estaduais e municipais pertinentes, reconhecendo as diferenças geográficas de cada região, subentendendo-se que os problemas relacionados ao parcelamento e planejamento urbano nunca serão os mesmos, o que justifica ser de competência dos estados e municípios definir o limite de área a ser parcelada pela referida lei. ${ }^{30}$

Quanto à distinção do que se define por desmembramento e loteamento, a própria lei traz o conceito, sem grandes embaraços. Assim, temos por loteamento "[...] a subdivisão de gleba em lotes destinados a edificação, com abertura de novas vias de circulação, de logradouros públicos ou prolongamento, modificação ou ampliação das vias existentes". ${ }^{31}$ De outra banda, tem-se por desmembramento "[...] a subdivisão de gleba em lotes [...], com aproveitamento do sistema viário existente, desde que não implique na abertura de novas vias e logradouros públicos, nem no prolongamento, modificação ou ampliação dos já existentes". ${ }^{32}$

O Provimento no 21/2011 faz menção ao ato de loteamento, desmembramento, fracionamento ou desdobro de imóveis, urbanos ou urbanizados, como meios de parcelamento do solo. Frise-se que a principal diferença entre o desdobro (ou fracionamento) dos demais é que essa

29 Art. 1‥ [...] Parágrafo único - Os Estados, o Distrito Federal e os Municípios poderão estabelecer normas complementares relativas ao parcelamento do solo municipal para adequar o previsto nesta Lei às peculiaridades regionais e locais". BRASIL. Lei no 6.766 , de 19 de dezembro de 2002. Disponível em: <http://www.planalto.gov.br/ccivil03/leis/l6766. $\mathrm{htm}>$. Acesso em: 12 jun. 2017.

30 OLIVEIRA, Gustavo Burgos de. Loteamento, desmembramento, desdobro, loteamento fecha- do. Condomínio geral, condomínio edilício, condomínio horizontal de lotes e condomínio urbanístico. Noções básicas. Disponível em: <http://jus.com.br/artigos/10943/loteamento-desmembramento-des dobro-loteamentofechado\#ixzz3JAipKxCj>. Acesso em: 13 jun. 2017.

${ }^{31}$ BRASIL. Lei no 6.766, de 19 de dezembro de 1979. Art. $2^{\circ}, \S 1^{\circ}$, da referida lei. Disponível em: <http://www.planalto.gov.br/ccivil03/leis/l6766.htm>. Acesso em: 13 jun. 2017.

32 BRASIL. Lei no 6.766, de 19 de dezembro de 1979. Art. 2º, §2º da referida lei. Disponível em: <http://www.planalto.gov.br/ccivil_03/leis/l6766.htm>. Acesso em: 13 jun. 2017. 
modalidade de parcelamento não está contemplada na Lei Federal nº 6.766/79, sendo aceito apenas pela Corregedoria Geral da Justiça do RS - CGJ/RS, através do Projeto More Legal. O desdobro, em termos gerais, é a divisão da área do lote para formação de novo ou novos lotes, de modo que continuem a atender a legislação municipal acerca das dimensões mínimas.

Aliás, o desdobro deverá ser aprovado pela municipalidade, assim como os demais meios de parcelamento. O seu registro, contudo, não é previsto na Lei n 6.766/79, mas o artigo 428 da Consolidação Normativa Notarial e Registral - CNNR, dispõe que os Oficiais dos Cartórios de Registro de Imóveis deverão adotar medidas de cautela na verificação dos mapas e memoriais descritivos, a fim de que não se proceda nenhuma retificação sem 0 procedimento legal exigido. ${ }^{33}$

No restante, a lei trata do procedimento e dos documentos necessários para cada espécie de parcelamento escolhida e das infrações penais, o que não se pretende estudar nesse momento. $O$ que se pretendeu demonstrar até aqui é que a legislação não trouxe a definição exata de parcelamento do solo ilegal. Todavia, a doutrina apresenta os limites do regular que, por consequência, define o que são lotes irregulares/clandestinos.

Segundo Anelise Stifelman e Rochelle Garcez"34, "é regular o parcelamento urbano que atende a todas as exigências administrativas do Poder Público e, depois de aprovado, é registrado perante o Registro de Imóveis da circunscrição onde se encontra a gleba fracionada".

Assim, há distinção quanto à ilegalidade, irregularidade ou clandestinidade dos parcelamentos. É ilegal todo o parcelamento que não segue às regras técnico-administrativo-jurídicas exigidas em lei, que não foi

${ }^{33}$ Art. 429 - Nas hipóteses de desdobramento de imóveis urbanos e rurais, os Oficiais deverão adotar cautelas no verificar da área, medidas, características e confrontações dos imóveis resultantes, a fim de evitar que se façam retificações sem o procedimento legal. Provimento no 32/2006 da CGJ/RS - CNNR. Disponível em: $<$ http://www.cartorio.tjrs.ieses.org/documentos/ARQUIVOS/cnnrcgj012201 2.pdf>. Acesso em: 13 jun. 2017.

${ }^{34}$ STIFELMAN, Anelise Grehs; GARCEZ, Rochelle Jelinek. Do parcelamento do solo com fins urbanos em zona rural e da aplicação da Lei no 6.766/79 e do Provimento no 28/04 da CGJ/RS (Projeto More Legal). P. 01, 01-19. Artigo Científico. Disponível em: <www.mprs.mp.br/areas/urba nistico/arquivos/parcelamento.doc>. Acesso em: 13 jun. 2017. 
registrado junto ao Registro Imobiliário ou que não foi executado de acordo com os projetos. Já os irregulares são os parcelamentos que tiveram os projetos aprovados pelo Poder Público, porém não foram registrados no Registro de Imóveis ou suas obras não foram executadas e/ou foram em desacordo com a licença expedida, apesar da venda, cessão ou ocupação dos lotes terem sido efetivadas. Por fim, clandestinos são aqueles parcelamentos que não têm projeto aprovado pela autoridade municipal e, consequentemente, estão pendentes de registro, como leciona José Carlos de Freitas. ${ }^{35}$

Desta forma, uma vez que é crescente o número de loteamentos clandestinos ou irregulares no nosso país, principalmente em famílias de baixa renda, a edição - e atualização - do Projeto More Legal, como se verificará no próximo capítulo, foi fundamental no processo de regularização de desses loteamentos no nosso Estado.

\section{PROJETO MORE LEGAL}

Pioneiro no país, o projeto More Legal, de iniciativa da Corregedoria Geral de Justiça do Rio Grande do Sul - CGJ/RS, designou-se a encetar regras objetivas para a regularização de loteamentos, desmembramentos, fracionamentos ou desdobro de imóveis urbanos ou urbanizados, com a consequente legalização do exercício da posse, já em situações consolidadas, mediante o registro imobiliário.

\subsection{Desenvolvimento histórico do Projeto More Legal}

O Projeto More Legal foi idealizado, inicialmente, pelo Desembargador Décio Antônio Erpen, então Corregedor-Geral da Justiça do Estado do Rio

${ }^{35}$ FREITAS, José Carlos de. Loteamentos clandestinos: uma proposta de prevenção e repressão. São Paulo, Imprensa Oficial do Estado: Ministério Público do Estado de São Paulo, 2000. 
Grande do Sul, e foi editado pela primeira vez em 1995, através do provimento n³9/1995 - CGJ/RS, também conhecido como More Legal I ${ }^{36}$.

Posteriormente, o Projeto More Legal foi reeditado pelo Desembargador e Corregedor-Geral da Justiça Aristides de Albuquerque Neto, sendo instituído o Provimento n 17/1999 - CGJ/RS - More Legal II. Em breve análise, as principais considerações trazidas pelo projeto foram à proteção jurídica do adquirente do imóvel e as hipóteses de situações fáticas consolidadas e irreversíveis dada à destinação social do imóvel sob a ótica jurídica.

É pertinente enfatizar que o segundo projeto alterou parte da legislação em vigor tocante à matéria, ressaltando o interesse público em regularizar parcelamentos irregulares e clandestinos, vedando outras exigências que não a documentação mínima necessária ao registro.

Em 2004, foi publicado o provimento $n^{\circ} 28 / 2004-C G J / R S$, instituindo 0 Projeto More Legal III, também assinado pelo Desembargador Aristides de Albuquerque Neto. Somente através do Provimento n²8/2004 consagrou-se 0 direito à moradia como direito social fundamental do cidadão, sendo seu conceito introduzido pela Emenda Constitucional $n^{\circ} 26$, de 14 de fevereiro de 2000. ${ }^{37}$

Frise-se que os provimentos que originaram o More Legal II e III foram de extrema importância, uma vez que, através destes, se reconheceu a inviolabilidade da posse que atendesse a sua função social, tornando-a uma área de situação consolidada e, automaticamente, irreversível ao seu status quo anterior.

${ }^{36}$ WOLF, Guilherme Eidelwein. A regularização fundiária urbana no Brasil e seus instrumentos de alcance. Notas introdutórias acerca do direito fundamental à moradia frente às políticas públicas de regularização fundiária. Publicado em 09/2012. Elaborado em 06/2012. Disponível em: <http://www. jurisway.org.br/v2/dhall.asp?iddh=8957>. Acesso em: 13 jun. 2017.

37 Art. $6^{\circ}$. São direitos sociais a educação, a saúde, o trabalho, a moradia, o lazer, a segurança, a previdência social, a proteção à maternidade e à infância, a assistência aos desamparados, na forma desta Constituição. BRASIL. Emenda Constitucional no 26, de 14 de fevereiro de 2000. Disponível em: <http://www.planalto.gov.br/ccivil03/constituicao/ Emendas/Emc/emc26.htm>. Acesso em: 13 jun. 2017. 
Contudo, com a edição da Lei no 11.481/2007 prevendo medidas voltadas à regularização fundiária de interesse social em imóveis da União e da Lei no 11.977/2009 - a qual institui o Programa Minha Casa, Minha Vida e medidas para regularização fundiária de assentamentos localizados em áreas urbanas -, tornou-se necessário algum instrumento jurídico que se adequasse as novas normas, dando continuidade à viabilidade do projeto diante de situações clandestinas ou irregulares.

Desta forma, com pilares nas referidas leis, originou-se o Projeto More Legal IV, o qual é o ponto ápice do presente trabalho e se passará a explorar no próximo tópico.

\subsection{PROVIMENTO № 21/2011, CGJ/RS - PROJETO MORE LEGAL IV}

Nascido com pilares nas leis anteriormente referidas, o Projeto More Legal IV foi instituído pelo provimento no 21/2011-CGJ/RS, em 15 de junho de 2011, sendo assinado pelo Desembargador Ricardo Raupp Ruschel, então Corregedor-Geral da Justiça. Em uma linha cronológica, apesar de distante, o Projeto More Legal IV conseguiu seguir a linha do More Legal I. Nesse aspecto, Guilherme Wolf ${ }^{38}$ destaca que a quarta edição do projeto visa à regularização do lote individualizando, sendo o seu objetivo principal extinguir condomínios pro diviso ${ }^{39}$ existentes na área maior.

No tocante a regularização fundiária de interesse social, destaca-se que este Projeto foi editado, principalmente, no intuito de buscar uma solução às populações de baixa renda, pois visa regularizar, de forma coletiva e acessível, a clandestinidade ou irregularidade jurídica de inúmeras áreas, vez

38 WOLF, Guilherme Eidelwein. A regularização fundiária urbana no Brasil e seus instrumentos de alcance. Notas introdutórias acerca do direito fundamental à moradia frente às políticas públicas de regularização fundiária. Publicado em 09/2012. Elaborado em 06/2012. Disponível em: <http://www .jurisway.org.br/v2/dhall.asp?id_dh=8957>. Acesso em: 13 jun. 2017.

39 Nas palavras de Rizzardo, o condomínio se classifica em pro diviso e pro indiviso, onde a primeira modalidade o condomínio existe de direito, mas não de fato. Cada condômino se localiza numa parte certa e determinada do bem, exercendo nessa porção específica da coisa seu poder de uso, gozo e disposição exclusiva. Na segunda, a comunhão se realiza de fato e de direito, mas indivisamente, ou sem uma localidade delimitada do bem. RIZZARDO, Arnaldo. Direito das Coisas: Lei no 10.406, de 10.01.2002. Rio de Janeiro: Forense, 2011. 
que carentes desta regularização para usufruírem de benefícios construtivos do Poder Público.

Tal afirmativa está em concordância com as considerações iniciais que levaram a edição do provimento, onde se afirmou "a necessidade de preservarse o espírito de flexibilização na comprovação documental para a aquisição da propriedade, sem descuido de uma observância às normas que regulamentam os registros públicos [...]". ${ }^{40}$

Ademais, no que concerne ao tema do presente estudo, dar-se-á ênfase na análise do artigo 512 ao artigo 519, prosseguindo, posteriormente, a análise do artigo 526-A ao artigo 526-M, e posteriores disposições finais do Provimento n 21/2011, vez que os demais artigos abordam outras formas de regularização e disposições diversas sobre parcelamentos ou loteamentos, tais como a regularização com projeto aprovado conforme Lei no 11.977/2009, a legitimação da posse posterior marcação urbanística e a regularização de áreas pro diviso (a qual é mais bem amparada, ainda que de forma analógica, pelo Provimento no 07/2005 da CGJ/RS - Gleba Legal).

\subsubsection{Das disposições gerais do More Legal IV}

O Provimento no 21/2011 alterou o Capítulo XV da CNNR. Os documentos imprescindíveis para o procedimento, bem como as condições necessárias estão basicamente elencados no artigo 512 do provimento, demonstrando a necessidade da existência de prova capaz de corroborar a titulação do imóvel diante do judiciário, entre outros documentos indispensáveis. Vejamos:

Art. 512 - Nas comarcas do Estado do Rio Grande do Sul, em situações consolidadas, poderá a autoridade judiciária competente autorizar ou determinar o registro acompanhado dos seguintes documentos:

I - título de propriedade do imóvel ou, nas hipóteses dos $\S \S 3^{\circ} \mathrm{e}$ 4 ㅇ deste artigo, apenas a certidão da matrícula;

${ }^{40}$ RIO GRANDE DO SUL. Ministério Público. Preâmbulo do Provimento no 21/2011 da CGJ/RS. Disponível em: <http://www.mprs.mp.br/urbanistico/legislacao/id5904.htm>. Acesso em: 13 jun. 2017. 


\begin{abstract}
II - certidão de ação real ou reipersecutória, de ônus reais e outros gravames, referente ao imóvel, expedida pelo Ofício do Registro de Imóveis;

III - planta do imóvel e memorial descritivo, emitidos ou aprovados pelo Município.

$\S 1^{\circ}$ - Considera-se situação consolidada aquela em que o prazo de ocupação da área, a natureza das edificações existentes, a localização das vias de circulação ou comunicação, os equipamentos públicos disponíveis, urbanos ou comunitários, dentre outras situações peculiares, indique a irreversibilidade da posse titulada que induza ao domínio;

$\S 2^{\circ}-\mathrm{Na}$ aferição da situação jurídica consolidada, serão valorizados quaisquer documentos provenientes do Poder Público, em especial do Município;

$\S 3$ 3 - O título de propriedade será dispensado quando se tratar de parcelamento popular, destinado às classes de menor renda, em imóvel declarado de utilidade pública com processo de desapropriação judicial em curso e imissão provisória na posse, desde que promovido pela União, Estado ou Município, ou suas entidades delegadas, autorizadas por lei a implantar projetos de habitação;

$\S 4^{\circ}-$ No caso de que trata o $\S 3^{\circ}$, supra, o pedido de registro do parcelamento, além do documento mencionado no art. 18 , inc. $\mathrm{V}$, da Lei ํo 6.766, de 191279 , será instruído com cópias autênticas da decisão que tenha concedido a imissão provisória na posse, do decreto de desapropriação, do comprovante de sua publicação na imprensa oficial e, quando formulado por entidade delegada, da lei de criação e de seu ato constitutivo;

$\S 5^{0}-$ Nas regularizações coletivas poderá ser determinada a apresentação de memorial descritivo elaborado pelo Município, ou por ele aprovado, abrangendo a divisão da totalidade da área ou a subdivisão de apenas uma ou mais quadras.
\end{abstract}

De acordo com o dispositivo, percebe-se a necessidade de um título que seja capaz de suportar o ônus probatório da posse/propriedade, o qual deverá conter os requisitos básicos de um contrato e modo de aquisição que, segundo João P. Paiva ${ }^{41}$, seria um "[...] binômio inafastável também enquanto condição jurídica para a realização das regularizações imobiliárias instituídas pelo Projeto More Legal". E é nesse momento que se torna oportuno um esclarecimento quanto ao procedimento adotado pelos cartórios registrais.

41 PAIVA, João Pedro Lamana. Parcelamento do solo urbano e suas respectivas repercussões no âmbito dos serviços notariais e registral imobiliário e a regularização fundiária urbana: Espécies: loteamento, desmembramento e fracionamento/desdobro. Disponível em: <http://www. google.com.br/url?sa=t\&rct=j\&q=\&esrc=s\&frm $=1$ \&source=web\&cd=1\&ved=0CB8QFjAA\&url= http\%3A\%e2F\%2Fwww.lamanapaiva.com.br\%2Fbanco_aulas\%2Fsanta\%2520cruz\%252025 20unisc\%2502520LOTEAMENTO\%2520e\%2520REGULARIZACAO\%2520FUNDIARIA.pdf\& ei=QE1HvjmUMsGaNsOzgeAl\&usg=AFQjCNEEf8hDDMc06Tc9TiplQcvlm_RCqA\&bvm=bv.7 9189006,d.eXY>. Acesso em: 25 jun. 2017. 
A comprovação do exercício da posse, mediante "contratos de compra e venda de posse", de acordo com o Provimento $n^{\circ} 21 / 2011$, viria somente após a regularização do loteamento, conforme estipula o artigo 526-A. Contudo, muitos Oficiais acabam por adotar em seus cartórios o recolhimento prévio dos contratos (juntamente com o primeiro requerimento), pois muitos carecem de condições básicas de validade, e até mesmo são inexistentes (compra e venda verbal, por simples recibo, entre outros).

Deste modo, uma vez que ao Oficial compete apenas verificar os quesitos registrais, ou seja, a viabilidade de registro da demanda pleiteada, este se socorre do judiciário, amparado pela Constituição Federal, para que o Douto Magistrado avalie a validade jurídica do documento evocado para reconhecimento do direito de "comprador-possuidor direto" e, então, valide os seus registros perante a serventia.

Portanto, fica apenas a ressalva quanto ao procedimento adotado, pois analisaremos melhor, posteriormente, a fase de registro dos respectivos contratos. Nesse momento, o que inicialmente importa é o apontamento pelo requerente da matrícula ou registro que corresponda ao imóvel objeto da regularização, a fim de que o Oficial possa verificar a viabilidade do pedido diante das normas e princípios registrais.

Em análise contínua ao artigo 512, o $3^{\circ}$ prevê a possibilidade de regularização por iniciativa do Poder Público em casos de parcelamento popular, destinado às classes de menor renda. A genialidade do referido parágrafo está na condição de dispensa do título de propriedade, vez que essas pessoas são carentes de recursos financeiros e de informações inerentes às transações de compra e venda e tendem a não possuir todos os documentos necessários para o procedimento, os quais são capazes de demonstrar a cadeia sucessória do título de propriedade. Deste modo, o Poder Público é competente para requerer a regularização em nome dos possuidores, ignorando matrícula do imóvel e documentos particulares, tais como os contratos, juntando apenas a certidão negativa de bens em nome do (s) respectivo (s) possuidor (es), expedida pelo Cartório de Registro de Imóveis, na 
intenção de demonstrar a carência de recursos, em especial de moradia legal conforme a norma.

Contudo, a utilização desse instrumento pelo Poder Público, atualmente, é limitada e extremamente controlada, pois ao proporcionar essa regularização, também está assumindo compromissos, de tempo certo, com os seus futuros

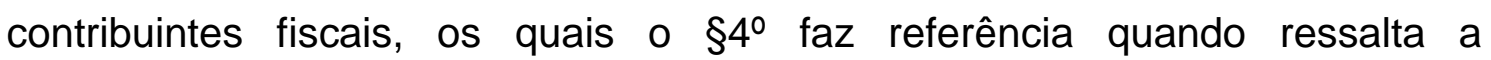
necessidade do documento mencionado no art. 18, inc. V, da Lei $n^{\circ}=6.766 / 79 .{ }^{42}$

Assim, entende-se que, na falta do loteador responsável pelo loteamento, e sendo a regularização iniciada pelo Poder Público, este deverá prover o saneamento básico, rede elétrica, divisão de ruas e calçamentos, além de outros fatores estruturais a todos os moradores, de forma a garantir a plenitude do direito da moradia legal.

Entretanto, a regularização do imóvel sempre será benéfica ao município, pois a emissão das guias de ITBI que acompanham o processo (ainda que imunes de tributação) permite que se atualize o cadastro das municipalidades para fins tributários. Desta forma, não somente o contribuinte estará lucrando em recursos, mas o Poder Público também, vez que muitas vezes oferece os serviços elencados sem nenhum controle de retorno dos indivíduos beneficiados.

Ademais, na explanação de Eliane Pagani ${ }^{43}$, ainda que a regularização do loteamento possa parecer apenas um benefício direto aos possuidores dos lotes em questão, toda a sociedade tende a ganhar, vez que se apresenta como uma solução para o enfrentamento do grave problema gerado pelo

\footnotetext{
${ }^{42}$ Art. 18. Aprovado o projeto de loteamento ou de desmembramento, o loteador deverá submetê-lo ao registro imobiliário dentro de 180 (cento e oitenta) dias, sob pena de caducidade da aprovação, acompanhado dos seguintes documentos: [...] V - cópia do ato de aprovação do loteamento e comprovante do termo de verificação pela Prefeitura Municipal ou pelo Distrito Federal, da execução das obras exigidas por legislação municipal, que incluirão, no mínimo, a execução das vias de circulação do loteamento, demarcação dos lotes, quadras e logradouros e das obras de escoamento das águas pluviais ou da aprovação de um cronograma, com a duração máxima de quatro anos, acompanhado de competente instrumento de garantia para a execução das obras; BRASIL. Lei no 6.766, de 19 de dezembro de 1979. Dispõe sobre o Parcelamento do Solo Urbano e dá outras Providências. Disponível em: <http://www.planalto.gov.br/ccivil_03/leis/ 16766.htm>. Acesso em: 25 jun. 2017.

${ }^{43}$ PAGANI, Eliane Adelina. O direito de propriedade e o direito à moradia: um diálogo comparativo entre o direito de propriedade urbana imóvel e o direito à moradia. Porto Alegre: EDIPUCRS, 2009. p. 56.
} 
crescimento desorganizado das cidades. Trata-se de um interesse social, visto que objetiva o crescimento e desenvolvimento organizado das cidades, o que 0 artigo 513 do provimento reafirma, ao tornar essa regularização de interesse social isenta de custas ou emolumentos notariais ou de registro.

Ocorre que, atualmente, a participação do Poder Público é muito mais colaborativa do que de iniciativa pois, uma vez que, na maioria dos casos, o ente não vislumbra a responsabilização do loteador clandestino ou irregular como prioridade, a regularização através do More Legal acaba sendo provida pelos possuidores - através de advogado particularmente contratado por eles , sendo que o Município só tende a colaborar com a emissão das certidões públicas necessárias. $^{44}$

Além disso, quanto à responsabilização dos loteadores faltosos, ainda há uma previsão no art. 514, $\S \S 1^{\circ}, 2^{\circ}$ e $3^{\circ}$, que autoriza o Município a requerer, mediante parecer favorável do Ministério Público - MP, a concessão de alvará que autorize o Município a firmar contratos de alienação de imóveis pendentes e promover a venda dos lotes remanescentes do loteamento, o qual poderá reverter a quantia apurada em benefício da Municipalidade para ressarcimento das despesas decorrentes da regularização.

Nesse caso, o Município deverá instruir seu requerimento com todos os documentos comprobatórios dos gastos obtidos, sejam públicos ou privados, o laudo de avaliação dos lotes e comprovar as despesas tidas na regularização, sendo facultada a utilização de prova testemunhal. $E$, em caso de dúvida dos valores apresentados pela Municipalidade na regularização e avaliação, o Juiz (de ofício) ou o Ministério Público (requerimento) poderão ensejar a realização de diligências ou perícias que entenderem necessárias para a comprovação complementar.

\footnotetext{
${ }^{44}$ PAIVA, João Pedro Lamana. Projeto More Legal IV: principais novidades introduzidas na CNNR. Artigo disponível em <http://www.google.com.br/url?sa=t\&rct=j\&q=\&esrc=s\&frm=1\&source=web\&cd =1\&ved=0CB0QFjAA\&url=http\%3A\%2F\%2Firib.org.br\%2Farquivos\%2Fbiblioteca\%2F4094art igo.pdf\&ei=veo2VNbvAo7DggSorICYDA\&usg=AFQjCNFqH2VjSmeg2fFulQMAQBIv9e8c4w>. Acesso em: 24 jun. 2017.
} 
Há, ainda, a previsão expressa no artigo $515^{45}$ de que, ainda que não atendidos os requisitos urbanísticos previstos na Lei Federal nํ⒍766/79, a autoridade judiciária poderá permitir o registro. Tal previsão demonstra a dimensão do reconhecimento ao direito de propriedade no Rio Grande do Sul, visto que em prol da defesa de um direito fundamental do ser humano, poderá, por vezes, "ignorar" - desde que não viole direito alheio - as diretrizes gerais estabelecidas em legislação federal ou municipal.

No segmento, após identificarmos os documentos fundamentais ao requerimento, estudaremos o procedimento do processo, avaliando seus aspectos funcionais e principais características.

\subsubsection{Do procedimento}

Depois de vencidas as questões acerca dos documentos necessários para regularização através do More Legal, passamos a estudar o procedimento para protocolamento do pedido de regularização.

O pedido, obedecendo aos requisitos do artigo 512, será apresentado ao Oficial do Cartório de Registro Imobiliário, o qual fará o protocolo e a autuação do requerimento e de todos os documentos que o acompanharem. Não obstante, também fará a conferência dos documentos apresentados, verificando sua regularidade em atenção aos princípios registrais, conforme prevê o artigo 516 do Provimento.

O §1ำ do artigo 516 dispõe que, uma vez em ordem, o pedido será remetido à Vara de Direção do Foro (no caso de Comarcas do interior) ou à Vara dos Registros Públicos (na Comarca da Capital) para decisão, que somente ocorrerá após a manifestação do órgão do Ministério Público. Significa dizer que o requerimento deverá estar devidamente acompanhado dos documentos particulares dos possuidores (cópias autenticadas de CPF/RG e

\footnotetext{
${ }^{45}$ Art. 515 - Nas hipóteses de regularização previstas no presente título, a autoridade judiciária poderá permitir o registro, embora não atendidos os requisitos urbanísticos previstos na Lei no 6.766, de 19-12-79 ou em outros diplomas legais. RIO GRANDE DO SUL. Corregedoria Geral de Justiça. Provimento no 21/2011. (Projeto More Legal IV). Disponível em: <http://www.mprs.mp.br/urbanis tico/legislacao/ id5904.htm>. Acesso em: 25 jun. 2017.
} 
registro civil), bem como os documentos atinentes ao imóvel em questão (certidão de matrícula atualizada, plantas e memorais descritivos da área a ser desmembrada e da área remanescente, se houver, e, se for o caso, os "contratos" que intitulam a posse), além dos documentos emitidos pelo próprio Poder Municipal (certidão de situação consolidada, certidão de área urbana ou urbanizada, entre outras que forem necessárias).

Como em qualquer solicitação de fracionamento ou desmembramento, o mapa, acompanhado do memorial descritivo, deverá ter a assinatura de anuência dos lindeiros, atestando que os mesmos concordam com as suas medidas e que nada têm a opor ao procedimento almejado. ${ }^{46}$ Contudo, não ocorrendo a anuência dos lindeiros no mapa e memorial descritivo, deverá o Oficial realizar a notificação dos mesmos em conformidade com o artigo 213, II, $\S \S 2^{\circ}$ e $3^{\circ}{ }^{47}$, da Lei Federal $n^{\circ}$ 6.015, conforme prevê 0 artigo 518 do Provimento $\mathrm{n}^{\circ}$ 21/2011.

Outra situação interessante é que, em caso de outras exigências que não forem sanadas administrativamente, o Oficial poderá, a pedido do apresentante (no caso poderá ser o Município, o loteador ou os possuidores), remeter a documentação ao Juiz de Direito para apreciação conjunta da

${ }^{46}$ De acordo com o art. 213, II, da Lei 6.015/73, o qual determina que o Oficial retificará o registro ou a averbação "a requerimento do interessado, no caso de inserção ou alteração de medida perimetral de que resulte, ou não, alteração de área, instruído com planta e memorial descritivo assinado por profissional legalmente habilitado, com prova de anotação de responsabilidade técnica no competente Conselho Regional de Engenharia e Arquitetura CREA, bem assim pelos confrontantes". BRASIL, Lei no 6.015, de 31 de dezembro de 1973 (Lei dos Registros Públicos). Disponível em: <http://www.planalto.gov.br/ccivil_03/leis/l6015.htm?>. Acesso em: 25 jun. 2017

${ }^{47}$ Art. $213[\ldots]$ II- [...] $2^{\circ}{ }^{\circ}$ Se a planta não contiver a assinatura de algum confrontante, este será notificado pelo Oficial de Registro de Imóveis competente, a requerimento do interessado, para se manifestar em quinze dias, promovendo-se a notificação pessoalmente ou pelo correio, com aviso de recebimento, ou, ainda, por solicitação do Oficial de Registro de Imóveis, pelo Oficial de Registro de Títulos e Documentos da comarca da situação do imóvel ou do domicílio de quem deva recebê-la. §3ํㅗ A notificação será dirigida ao endereço do confrontante constante do Registro de Imóveis, podendo ser dirigida ao próprio imóvel contíguo ou àquele fornecido pelo requerente; não sendo encontrado o confrontante ou estando em lugar incerto e não sabido, tal fato será certificado pelo oficial encarregado da diligência, promovendo-se a notificação do confrontante mediante edital, com o mesmo prazo fixado no $\S 20$, publicado por duas vezes em jornal local de grande circulação. BRASIL, Lei no 6.015, de 31 de dezembro de 1973 (Lei dos Registros Públicos). Disponível em: <http://www.planalto.gov.br/ccivil_03/leis//6015. htm?>. Acesso em: 25 jun. 2017. 
exigência e do pedido de regularização. ${ }^{48}$ Essa previsão abre uma possibilidade de análise de documentos adversos dos necessários, mas que, por ventura, poderiam ser apresentados na falta desses. É o caso dos contratos formalizados verbalmente, anteriormente exposto.

Tal alternativa demonstra que, através do Projeto More Legal busca-se, principalmente, o estudo das situações adversas (e juridicamente válidas), as quais não estão amparadas na letra da lei existente ou carecem de esclarecimentos acerca de conceitos mais complexos para fins de uniformização do procedimento, necessitando de uma apreciação jurisdicional plena para ver reconhecida a condição de "possuidor/proprietário" do bem em questão. É o reconhecimento de que a lei, por mais ampla que possa ser, talvez não consiga atingir a todas as situações que se apresentem diante dela de forma justa sem essa intervenção.

Em análise contínua, apesar de não expresso no Provimento $n^{\circ}$ 21/2011, União, Estado e Município serão citados para manifestar eventual interesse (ou não) na demanda. Da mesma forma, poderá o Juiz determinar a publicação de edital para conhecimento de terceiros, suspendendo o julgamento até o término do prazo para manifestações (art.516, §3).

Quanto ao trâmite do processo, este será regido pelas normas que regulam a jurisdição voluntária, aplicando-se, no que couber, a Lei № 6015/73 (Lei dos Registros Públicos), atendendo-se, sempre, os critérios de conveniência e/ou oportunidade (art. 516, $4^{\circ}$ ). Concluído os trâmites procedimentais, os autos se farão conclusos ao Juiz de Direito para sentença.

Independente de sentença procedente ou não, os autos retornaram ao Cartório de Registro de Imóveis responsável pelo protocolo, para simples arquivamento ou cumprimento das determinações judiciais e posterior arquivamento. O que deve ser compreendido aqui é que o processo, independente da intervenção judicial, é de competência do Oficial, ou seja,

${ }^{48}$ Art. $516[\ldots] \S 2^{\circ}-$ Havendo exigência a ser satisfeita, o Oficial a indicará por escrito. Não se conformando o apresentante, requererá que o Oficial remeta a documentação ao Juiz de Direito competente para a apreciação conjunta da exigência e do pedido de regularização. RIO GRANDE DO SUL. Corregedoria Geral de Justiça. Provimento no 21/2011 (Projeto More Legal IV). Disponível em: <http://www.mprs.mp.br/urbanistico/legislacao/id5904.htm>. Acesso em: 25 jun. 2017. 
cabe a ele o seu registro, arquivamento e guarnecimento pelo prazo previsto em lei.

O artigo 517 dispõe que o Juiz pode determinar a retificação da descrição da área regularizada, caso seja necessário, com base na respectiva planta e memorial descritivo que acompanham o processo. ${ }^{49} \mathrm{O}$ dispositivo é inteligente e extremamente viável, pois abrange a situação de alguns imóveis que são cortados por estradas e rodovias e estão pendentes dessas atualizações e averbações nas suas matrículas, as quais somente podem ocorrer com material elaborado por técnico competente, juntamente com a Anotação de Responsabilidade Técnica - ART.

Ao fim da fase procedimental, o art. 519 estabelece que o registro e a respectiva matrícula são passíveis de cancelamento por situações previstas em lei, em especial as hipóteses do art. 216, da Lei $n^{0} 6.015 / 73^{50}$, e que a constatação de algum ato por ele autorizado, que seja nulo ou anulável diante de processo, poderá ensejar o cancelamento de ofício ou por representante do MP, conforme elementos que forem alcançados para as providências cabíveis (art. 519, parágrafo único).

\subsubsection{Da localização de áreas em condomínio}

Até o presente momento, o Projeto More Legal muito se assemelha a um procedimento de loteamento regular ou aquisição da propriedade por meio de usucapião individual ou coletiva. Contudo, aos dois se difere (e muito), visto que no primeiro existe um loteador responsável, preocupado em atender as exigências técnicas e burocráticas da lei; no segundo porque a usucapião visa

${ }^{49}$ Art. 517 - No caso de a área parcelada não coincidir com a descrição constante no registro imobiliário, o Juiz determinará a retificação da descrição do imóvel com base na respectiva planta e no memorial descritivo. RIO GRANDE DO SUL. Provimento no 21/2011 - CGJ (Projeto More Legal IV). Disponível em: <http://www.mprs.mp.br/urbanistico/legislacao/id5904.htm>. Acesso em: 25 jun. 2017.

${ }^{50}$ Art. 216 - O registro poderá também ser retificado ou anulado por sentença em processo contencioso, ou por efeito do julgado em ação de anulação ou de declaração de nulidade de ato jurídico, ou de julgado sobre fraude à execução. BRASIL. Lei no 6.015 , de 31 de dezembro de 1973 - Lei dos Registros Públicos. Disponível em: <http://www.planalto.gov.br/ccivil_03/leis//6015.htm>. Acesso em: 25 jun. 2017. 
à regularização da titularidade do bem, apenas, procedendo na averbação de todos os acessórios que o acompanham (a exemplo das benfeitorias).

O Projeto More Legal, ao contrário, busca regularização do parcelamento da terra nua, do loteamento que, por omissão de responsável direto, deixou de ser feito conforme as diretrizes legais. Procede no reconhecimento das ruas que já existem de fato e na abertura de matrículas individuais - em nome do proprietário do imóvel, de acordo com a matrícula que fora juntada quando do início do requerimento. A transferência da titularidade do imóvel só se transferirá quando do registro dos contratos perante o Oficial. ${ }^{51}$

Se ignorássemos a ressalva feita anteriormente quanto à validade dos contratos apresentados pelos possuidores, poderíamos afirmar, então, que "entregar" a titularidade do imóvel ao possuidor independe de determinação ou intervenção judicial, cabendo ao Oficial da serventia essa atribuição. Entretanto, a análise dos contratos pelo Juiz de Direito ainda reside somente na sua validade civil $^{52}$, sendo assim, o procedimento abarca o registro dos contratos pelo Oficial, independente da benfeitoria existente no lote (que deverá ser averbada posteriormente).

Ainda nessa linha comparativa, um dos diferenciais do procedimento é a possibilidade de localização da área em condomínio, ou seja, se a matrícula possuir diversos condôminos, estranhos ao procedimento, vez que o requerimento se restringe a uma fração ideal do todo, poderá o Juiz determinar a sua "retirada" do condomínio, onde o Oficial procederá na abertura de uma nova matrícula ${ }^{53}$ somente para aquela fração ou cada uma das frações, descontando as suas respectivas áreas do todo maior que se encontra em

${ }^{51}$ SALLES, José Carlos de Moraes. Usucapião de bens imóveis e móveis. São Paulo: Revista dos Tribunais, 2010. p. 240.

52 Art. 104. A validade do negócio jurídico requer: I - agente capaz; II - objeto lícito, possível, determinado ou determinável; III - forma prescrita ou não defesa em lei. BRASIL. Código Civil de 2002. Disponível em: <http://www.planalto.gov.br/ccivil_03/leis/2002/110406.htm>. Acesso em: 25 jun. 2017.

${ }^{53}$ Art. 526-D - Procedido o registro ou a averbação previstos neste projeto, o Oficial do Registro de Imóveis abrirá matrícula própria, se o imóvel ainda não a tiver, bem como das áreas públicas previstas no projeto. RIO GRANDE DO SUL. Corregedoria Geral de Justiça. Provimento no 21/2011 (Projeto More Legal IV). Disponível em: <http://www.mprs.mp.br/urbanistico/legislacao/id5904.htm>. Acesso em: 25 jun. 2017. 
estado de comunhão. Vejamos o texto do artigo 526-B do Provimento no

21/2011:

\begin{abstract}
Art. 526-B - Em imóveis situados nos perímetros urbanos, assim como nos locais urbanizados, ainda que situados na zona rural, em cujos assentos conste estado de comunhão, mas que, na realidade, se apresentam individualizados e em situação jurídica consolidada, nos termos deste provimento, o Juiz poderá autorizar ou determinar a averbação da identificação de uma ou de cada uma das frações, observado o seguinte:

I - Anuência dos confrontantes da fração do imóvel que se quer localizar, expressa em instrumento público ou particular, neste caso com as assinaturas reconhecidas, entendidos como confrontantes aqueles previstos no $\S 10$ do art. 213 da Lei $n^{\circ} 6.015 / 73 ;{ }^{54}$

II - A identificação da fração de acordo com o disposto nos arts. 176, inciso II, no 3, letra b, e 225 da Lei no 6.015/73, por meio de certidão atualizada expedida pelo Poder Público Municipal.
\end{abstract}

Deste modo, a localização depende da anuência dos confrontantes de fato, ou seja, os confrontantes da área que se pretende regularizar, e não da matrícula de direito.

Assim, percebe-se que o intuito do More Legal IV é a regularização de loteamentos constituídos por contratos de compra e venda informais, tornando a situação consolidada em registro hábil para o exercício da propriedade.

Igualmente, quanto aos imóveis rurais, percebe-se que o Provimento no 21/2001 manteve a regularização do parcelamento efetuado em terras rurais que tenham comprovada destinação urbana, conforme o provimento anterior. Isto porque o terreno não serve tão simplesmente como local de plantação e sustento da família, mas sim, representando, acima de tudo, o lar do grupo familiar, que pode exercer atividades rurais, mas não como única fonte de renda.

Entretanto, para que os loteamentos clandestinos ou irregulares preencham os requisitos essenciais, é indispensável a presença da situação

\footnotetext{
${ }^{54}$ Art. 213. O oficial retificará o registro ou a averbação: § 10. Entendem-se como confrontantes não só os proprietários dos imóveis contíguos, mas, também, seus eventuais ocupantes; o condomínio geral, de que tratam os arts. 1.314 e seguintes do Código Civil, será representado por qualquer dos condôminos e o condomínio edilício, de que tratam os arts. 1.331 e seguintes do Código Civil, será representado, conforme o caso, pelo síndico ou pela Comissão de Representantes. BRASIL. Lei no 6.015, de 31 de dezembro de 1973 (Lei dos Registros Públicos). Disponível em: <http://www.planalto. gov.br/ccivil_03/leis/l6015.htm?>. Acesso em: 25 jun. 2017.
} 
consolidada, a qual demonstra a irreversibilidade da situação existente no condomínio que se pretende regularizar.

\subsubsection{Da situação consolidada e sua irreversibilidade}

Tendo em vista o exposto até aqui, faz-se necessário o esclarecimento do artigo 512, $\S 1^{\circ}$, do Provimento $n^{\circ} 21 / 2011$. Isto porque a introdução do termo jurídico "situação consolidada" na esfera do direito posto ocorreu através do Projeto More Legal, tão logo na sua primeira edição.

Nesse sentido, apesar do seu conceito ter sido explorado somente a partir do More Legal III, a situação consolidada confere aos loteamentos irregulares ou clandestinos, desde o nascimento da ideologia do provimento, uma característica primordial: a irreversibilidade.

Baseado nos princípios sociais e individuais, não se pode deixar de considerar a validade daquele lar instaurado tão simplesmente pela falta do registro do imóvel. A existência de uma situação consolidada faz com que a maioria desses lotes - irregulares ou clandestinos - não possam ficar desamparados, por força do caráter social presente nas normas constitucionais.

A situação consolidada da área a ser regularizada, para fins de aplicabilidade do Provimento $n^{\circ} 21 / 2011$, é extremamente necessária, tanto que, no art. 512, $\S 1^{\circ}$, da CNNR, alterado pelo provimento, encontramos a melhor definição para tal característica. Vejamos:

Art. $512-[\ldots] \S 1^{\circ}$ - Considera-se situação consolidada aquela em que o prazo de ocupação da área, a natureza das edificações existentes, a localização das vias de circulação ou comunicação, os equipamentos públicos disponíveis, urbanos ou comunitários, dentre outras situações peculiares, indique a irreversibilidade da posse titulada que induza ao domínio;

E o requisito de situação consolidada é fundamental para a procedência do pedido de regularização de imóveis através do Projeto More Legal IV. Vejamos: 


\begin{abstract}
APELAÇÃO CÍVEL. REGISTRO DE IMÓVEIS. PROJETO MORE LEGAL IV. PROVIMENTO № 21/2011 - CGJ. REGULARIZAÇÃO E ABERTURA DE MATRÍCULA. REQUISITO DE SITUAÇÃO CONSOLIDADA PREENCHIDO. APELO DESPROVIDO. PROCEDÉNCIA MANTIDA. Projeto more legal. Provimento $\mathrm{n}^{\circ}$ 21/2011 - CGJ. Nas comarcas do Estado do Rio Grande do Sul, em situações consolidadas, poderá a autoridade judiciária competente autorizar ou determinar o registro. Considera-se situação consolidada aquela em que o prazo de ocupação da área, a natureza das edificações existentes, a localização das vias de circulação ou comunicação, os equipamentos públicos disponíveis, urbanos ou comunitários, dentre outras situações peculiares, indique a irreversibilidade da posse titulada que induza ao domínio. A intenção do provimento é a inclusão social, a propriedade como instrumento de cidadania, inviolabilidade do direito á propriedade, consagração dos direitos de propriedade e promoção da justiça social. Caso. Situação comprovada. A existência de benfeitoria não é condição sine qua non de regularização através do projeto more legal, mas sim a situação consolidada da posse. Sentença mantida. NEGARAM PROVIMENTO AO APELO. UNÂNIME. ${ }^{55}$
\end{abstract}

Percebe-se, por conseguinte, que não fora estabelecido decurso de tempo mínimo de ocupação na hipótese de regularização através do Projeto More Legal IV. Tampouco é exigida a cumulatividade dos elementos acima descritos como caracterizadores da situação consolidada, sendo admitida a alternatividade destes, de modo a não "engessar" a aplicação da norma e obstaculizar a aquisição da propriedade imobiliária quando constatada a irreversibilidade da posse e o "animus domini". 56

Com base nessas considerações, é possível observar que a situação consolidada é requisito intrínseco a regularização proposta pelo Projeto More Legal e, posteriormente a sentença procedente com trânsito em julgado, haverá o registro dos contratos por parte do Registro de Imóveis.

${ }^{55}$ RIO GRANDE DO SUL. Décima Sétima Câmara Cível, Tribunal de Justiça, Apelação Cível № 70069606333. Relator: Giovanni Conti, Julgado em 30/06/2016). Disponível em: $<$ http://www1.

tjrs.jus.br/sitephp/consulta/consulta_processo.php?nome_comarca=Tribunal+de+Justi\%E7a\& versao $=\&$ versao fonetica $=1$ \&tipo $=1$ \&id_comarca $=700 \&$ num_processo_mask $=70069606333 \&$ num_processo $=\overline{7} 0069606333 \&$ codEmenta $=6841819 \&$ tem IntTeor $=$ true $>$. Acesso em: 01 jul. 2017.

${ }^{56}$ Vide STIFELMAN, Anelise Grehs; GARCEZ, Rochelle Jelinek. Do parcelamento do solo com fins urbanos em zona rural e da aplicação da lei no 6.766/79 e do provimento no 28/04 da CGJ/RS (Projeto More Legal); Artigo Científico. P. 15. Disponível em: <http://www.mprs.mp.br/urbanistico/doutrina/id344.htm>. Acesso em: 25 jun. 2017. 


\subsubsection{Do registro dos contratos e disposições finais}

Por derradeiro, resta o estudo do procedimento para registro dos contratos, o qual ocorre após a regularização e localização do loteamento.

Quanto ao registro, então, o artigo 526-A prevê que cabe aos adquirentes dos lotes, ora até então possuidores, requerer o registro dos seus contratos, padronizados ou não, levando-os até o Ofício de Registro de Imóveis. Entretanto, como antes destacado, muitos Oficiais tendem a solicitálos junto com a documentação necessária para regularização do loteamento, pelas razões já anteriormente relacionadas. Deste modo, quando isso ocorre, não há a necessidade dos adquirentes se deslocarem, individualmente, com os seus contratos para registro, pois o Oficial fará "de ofício" quando do retorno dos autos do Poder Judiciário.

$E$, quando se trata de regularização de interesse social, ou seja, promovida pelo Município, se torna compreensível a medida adotada pelos cartórios imobiliários. A lógica é simples: por se tratar de pessoas de baixa renda, elas não teriam condições de arcar com o custo dos registros dos contratos, ficando a iniciativa do Município sem alcançar o objetivo almejado, visto que a regularização do loteamento só acarretaria na abertura das matrículas (no mesmo número de lotes) em nome do até então proprietário, ora loteador faltoso.

Deste modo, verifica-se que o recolhimento prévio dos contratos garante jurisdição efetiva a todos os requerentes, eis que todo o procedimento incluindo registro dos contratos - será de interesse social. Mas, frise-se, tal entendimento não é unânime e sequer está na CNNR, sendo que pela letra da lei os contratos só seriam apresentados posteriores a regularização do loteamento e eventual localização de condomínio. Ademais, o §1ํ do Art. 526$A^{57}$ estipula que o requerente, caso necessário, poderá obter o registro nos

57 [...] $\S 1$ ํ - O registro poderá ser obtido diante da comprovação idônea da existência do contrato, nos termos do art. 27 , $\S \S 1^{\circ}$ e $2^{\circ}$, da Lei ํㅡ 6.766, de 19.12.1979. RIO GRANDE DO SUL. Corregedoria Geral de Justiça. Provimento no 21/2011 (Projeto More Legal IV). Disponível em: <http://www. mprs.mp.br/ urbanistico/legislacao/id5904.htm>. Acesso em: 25 jun. 2017. 
termos do art. $27, \S \S 1^{\circ}$ e 2 , da Lei $n^{\circ}$ 6.766, de 19.12.1979 ${ }^{58}$, o que condiciona uma garantia maior de que o contrato poderá ser registrado, sem necessária intervenção judicial para atestar a validade do contrato. Nesse sentido, o $6^{\circ}$ do Artigo 526-A estipula:

[...] § 6 - Os compromissos de compra e venda, as cessões e as promessas de cessão, valerão como título para o registro da propriedade do lote adquirido, quando acompanhados da respectiva prova de quitação das obrigações do adquirente e de guia de pagamento ou de exoneração do ITBI, registro esse que será feito a requerimento escrito do adquirente, sendo essa regra aplicável somente nos casos do $\S 3^{\circ}$ deste artigo.

Assim, verificamos que, em relação ao registro dos contratos, o Provimento no 21/2011 tentou abarcar uma vasta possibilidade dos quais poderiam ser apresentados como títulos de aquisição da propriedade pelos possuidores, de modo que a presença judicial para validar os atos do procedimento fosse mínima, demonstrando a intenção de preservação do espírito de flexibilização do Provimento quando da comprovação documental para a aquisição da propriedade perante a serventia.

Ademais, quanto à falta de qualificação das partes adquirentes nos contratos, os possuidores poderão comprová-la por meio de cópia autenticada do documento pessoal de identificação (Carteira Nacional de Habilitação, Título de Eleitor, Cartão de Identidade do Contribuinte do Imposto de Renda, Identidade Funcional ou Carteira Profissional e Certificado Militar, cf. art. 1ํㅡ da

${ }^{58}$ Art. 27. Se aquele que se obrigou a concluir contrato de promessa de venda ou de cessão não cumprir a obrigação, o credor poderá notificar o devedor para outorga do contrato ou oferecimento de impugnação no prazo de 15 (quinze) dias, sob pena de proceder-se ao registro de pré-contrato, passando as relações entre as partes a serem regidas pelo contrato-padrão.

$\S 1$ 1 Para fins deste artigo, terão o mesmo valor de pré-contrato a promessa de cessão, a proposta de compra, a reserva de lote ou qualquer, outro instrumento, do qual conste a manifestação da vontade das partes, a indicação do lote, o preço e modo de pagamento, e a promessa de contratar.

$\S 2^{\circ} \mathrm{O}$ registro de que trata este artigo não será procedido se a parte que o requereu não comprovar haver cumprido a sua prestação, nem a oferecer na forma devida, salvo se ainda não exigível. BRASIL. Lei no 6.766, de 19 de dezembro de 1979. Dispõe sobre o Parcelamento do Solo Urbano e dá outras Providências. Disponível em: <http://www.planalto.gov.br/ccivil_03/leis//6766.htm>. Acesso em: 25 jun. 2017 
Lei $\left.n^{0} 9.049 / 95\right)^{59}$, sendo que o estado civil é comprovado mediante cópia da certidão de casamento ou equivalente, conforme previsto no Art. 526, $2^{\circ}{ }^{\circ}$, do Provimento.

Por fim, nas suas disposições finais, o Provimento $\mathrm{n}^{\circ}$ 21/2011, em seu Art. 526-I, determina que, em caso de impugnação ao pedido de regularização dentro do processo judicial, a autoridade judiciária deverá remetê-los ao Oficial do Ofício de Registro de Imóveis para apreciação da impugnação. Entretanto, o parágrafo único do mesmo artigo dispõe que o juiz poderá rejeitar a impugnação de plano, caso julgue-a manifestadamente inadmissível ou improcedente, devendo julgar (avaliar) imediatamente o pedido inicial.

Suplantado os principais aspectos acerca do registro dos contratos dos possuidores, passaremos as considerações finais do trabalho.

\section{CONSIDERAÇÕES FINAIS}

Conforme foi possível perceber ao longo do presente estudo, a posse, dotada de função social, ainda que não esteja tacitamente prevista no texto constitucional brasileiro, é amplamente protegida por nosso ordenamento jurídico através do princípio da dignidade da pessoa humana, operando de forma analógica a função social da propriedade, sendo que milhares de famílias se encontram a margem da legislação vigente por carecerem do registro imobiliário.

Do mesmo modo, verificou-se que loteamentos irregulares ou clandestinos apresentam características semelhantes, sendo que seus vícios, ora urbanísticos, formais ou meramente normativos, não são impeditivos da regularização quando estes apresentam irreversibilidade da situação já consolidada.

No que se atenta ao parcelamento do solo, tendo em vista a ineficiência das demais leis ordinárias e políticas públicas, a iniciativa da CorregedoriaGeral de Justiça do Estado do Rio Grande do Sul demonstrou-se eficaz e

59 BRASIL. Lei Federal no $\mathbf{9 . 0 4 9}$, de 18 de maio de 1995. Disponível em: <http://www.planalto.gov. br/ccivil_03/Leis/L9049.htm>. Acesso em: 01 jul. 2017. 
fundamental para a diminuição de situações irregulares ou clandestinas, tutelando, ao transcorrer dos anos, os direitos de propriedade e de moradia presentes na Constituição Federal, em especial para os possuidores de baixa renda. Contudo, por tratar-se de um projeto pioneiro dos Tribunais de Justiça do Rio Grande do Sul, o desconhecimento do Projeto More Legal acaba por desestimular o interesse na sua utilização por parte de diversos grupos envolvidos (possíveis beneficiados, profissionais da área, além dos próprios agentes públicos envolvidos no trâmite), fazendo com que o mesmo ainda não consiga, de forma satisfatória, o resultado que dele se espera.

Questões atinentes à distribuição de energia elétrica e água tratada, bem como o alcance da rede de esgoto à área a ser regularizada deverão ser promovidas pelo Poder Público, uma vez que dentro dos perímetros urbanos do município.

Quanto ao texto normativo e ao procedimento previsto no Provimento $n^{\circ}$ 21/2011-CGJ/RS, pela estruturação simples e ausência de burocratização, este demonstra comprometimento com a intenção de regularização da situação jurídica dos possuidores de lotes em loteamentos irregulares ou clandestinos, os quais não conseguem gozar dos seus direitos como "proprietários" do imóvel de forma efetiva, o que pode ocasionar, em muitos casos, a protelação do sonho da casa própria de muitas famílias diante da impossibilidade de aderir a programas de incentivo do governo por falta de registro hábil da propriedade.

Em relação ao procedimento adotado por alguns Oficiais do Registro de Imóveis quanto ao recolhimento prévio dos contratos e outros instrumentos utilizados para "transferência da propriedade-posse", depreende-se o alcance dos princípios fundamentais do Projeto More Legal, visto que há uma preocupação da parte dos agentes envolvidos para que não haja impugnações ou situações que dificultem ou impeçam o efetivo registro do requerimento.

Deste modo, com base no estudo realizado e nas considerações até aqui explanadas, visualiza-se que a atual edição do Projeto busca a implantação da garantia constitucional que assegura o direito de propriedade, de forma a promover a imediata regularização das ocupações irregulares ou clandestinas e, por consequência, produzir efeitos positivos ao município de 
implantação, na medida em que dará cumprimento à função social da propriedade e arrecadará a contraprestação tributária para investimentos nas áreas de cunho social.

\section{REFERÊNCIAS}

ALBUQUERQUE, Ana Rita Vieira. Da Função Social da Posse e sua Consequên-cia Frente à Situação Proprietária. Rio de Janeiro: Editora Lumen Juris, 2002.

BALBIM, Renato. Avanços recentes no quadro normativo federal da regulariza-ção fundiária. In: Planejamento e políticas públicas, nº 34. Jan-jun de 2010. Brasília: IPEA, 2010. E-book. Disponível em:

<http://www.ipea.gov.br/ppp/index.php/ PPP/ article/viewFile/ 176/189>. Acesso em: 10 jun. 2017.

BRASIL. Código Civil de 2002. Disponível em:

<http://www.planalto.gov.br/ccivil_03 /leis/2002//10406.htm>. Acesso em: 25 jun. 2017.

BRASIL. Constituição da República Federativa do Brasil. Brasília, DF: Senado Federal, 1988.

BRASIL. Emenda Constitucional no 26, de 14 de fevereiro de 2000.

Disponível em:

<http://www.planalto.gov.br/ccivil03/constituicao/Emendas/Emc/emc26.htm>. Acesso em: 13 jun. 2017.

BRASIL, Lei no 6.015, de 31 de dezembro de 1973. Disponível em: <http:// www.pla nalto.gov.br/ccivil_03/leis/l6015.htm?>. Acesso em: 25 jun. 2017

BRASIL. Lei no 6.766, de 19 de dezembro de 2002. Disponível em: <http:// www.pla nalto.gov.br/ccivil03/leis/l6766.htm>. Acesso em: 12 jun. 2017.

BRASIL. Lei no 9.049, de 18 de maio de 1995 (BRASIL). Disponível em: <http://www.planalto. gov.br/ccivil_03/Leis/L9049.htm>. Acesso em: 19 nov. 2014.

BRASIL. Lei no 11.977, de 7 de julho de 2009. Disponível em: <http://www.pla nalto.gov.br/ccivil_03/_ato2007-2010/2009/lei//11977.htm>. Acesso em: 10 jun. 2017. 
BUCCI, Maria Paula Dallari. O conceito de política pública em direito. Políticas Públicas: reflexões sobre o conceito jurídico. São Paulo: Saraiva, 2006.

CHALHUB, Melhim Namem. Curso de Direito Civil: direitos reais. Rio de Janeiro: Forense, 2003.

DEBONI, Giuliano. Propriedade privada: do caráter absoluto à função social e ambiental: sistemas jurídicos italiano e brasileiro. Porto Alegre: Verbo Jurídico, 2011.

D'OTTAVIANO, Maria Camila Loffredo; SILVA, Sérgio Luís Quaglia.

Regularização fundiária no Brasil: velhas e novas questões. Brasília: IPEA, 2010. E-book. P. 202 - 201/229. Disponível em:

<http://www.ipea.gov.br/ppp/index.php/PPP/article/ view/172/ 185>. Acesso em: 11 jun. 2017.

FREITAS, José Carlos de. Loteamentos clandestinos: uma proposta de prevenção e repressão. São Paulo, Imprensa Oficial do Estado: Ministério Público do Estado de São Paulo, 2000.

IHERING, Rudolf von, 1818-1892. Teoria simplificada da posse. Tradutor Fernando Bragança. Belo Horizonte: Ed. Líder, 2004.

MARRA, Natalia Cardoso. Políticas públicas de habitação e a efetivação do direito social e fundamental à moradia. Publicado em 2010. Disponível em: $<$ http://www.conpedi.org.br/manaus/arquivos/anais/fortaleza/3309.pdf>. Acesso em: 10 jun. 2017.

MIRANDA, Pontes de. Tratado de Direito Privado - Tomo 5. Editora Bookseller.

OLIVEIRA, Gustavo Burgos de. Loteamento, desmembramento, desdobro, lotea-mento fechado. Condomínio geral, condomínio edilício, condomínio horizontal de lotes e condomínio urbanístico. Noções básicas. Disponível em: $<$ http://jus.com.br/ artigos/10943/loteamento-desmembramento-desdobroloteamento-fechado\#ixzz3 JAipKxCj>. Acesso em: 13 jun. 2017.

PAGANI, Eliane Adelina. $O$ direito de propriedade $\mathbf{e} 0$ direito à moradia: um diá-logo comparativo entre o direito de propriedade urbana imóvel e o direito à moradia. Porto Alegre: EDIPUCRS, 2009. P. 56.

PAIVA, João Pedro Lamana. Parcelamento do solo urbano e suas respectivas reper-cussões no âmbito dos serviços notariais e registral imobiliário e a regu-larização fundiária urbana: Espécies: loteamento, desmembramento e fraciona-mento/desdobro. Disponível em:

$<h t t p: / / w w w . g o o g l e . c o m . b r / u r l ? s a=t \& r c t=j \& q=\& e s$ 
$\mathrm{rC}=\mathrm{s} \& \mathrm{frm}=1 \&$ source $=$ web\& $\mathrm{cd}=1 \&$ ved=0CB8QFjAA\&url=http $\% 3 \mathrm{~A} \% 2 \mathrm{~F} \% 2 \mathrm{Fwww} . \mathrm{I}$ amanapaiva.com.br\%2Fbanco_aulas\%2Fsanta\%2520cruz\%25202520unisc\%2 50-2520

LOTEAMENTO\%2520e\%2520REGULARIZACAO\%2520FUNDIARIA.pdf\&ei=Q $\mathrm{E} 1 \mathrm{H}$

vjmUMsGaNsOzgeAI\&usg=AFQjCNEEf8hDDMc06Tc9TipIQcvlm_RCqA\&bvm= bv. 79189006,deXY>. Acesso em: 25 jun. 2017.

PAIVA, João Pedro Lamana. Projeto More Legal IV: principais novidades intro-duzidas na CNNR. Artigo disponível em

$<$ http://www.google.com.br/url?sa=t\&rct=

$j \& q=\&$ esrc $=s \& f r m=1 \&$ source $=$ web\& $c d=1 \& v e d=0 C B 0 Q F j A A \& u r l=h t t p \% 3 A \% 2 F \%$ 2

Firib.org.br\%2Farquivos\%2Fbiblioteca\%2F4094_artigo.pdf\&ei=veo2VNbvAo7D ggSorlCYDA\&usg=AFQjCNFqH2VjSmeg2fFulQMAQBlv9e8c4w>. Acesso em 24 jun. 2017.

PEREIRA, Caio Mário da Silva. Instituições de direito civil. Rio de Janeiro, Forense: Brasília, 1974.

PEREIRA, Caio Mário da Silva. Instituições de Direito Civil. Rio de Janeiro: Forense, 1995.

PEREIRA, Lafayette Rodrigues. Direito das coisas. Rio de Janeiro: Editora Rio, 1977.

REZENDE, Astolpho. A posse e sua proteção. Rio de Janeiro, 2000. Editora Lejus, 2. ed..

RIO GRANDE DO SUL. Corregedoria Geral de Justiça. Provimento no 32/2006. Disponível em:

<http://www.cartorio.tirs.ieses.org/documentos/ARQUIVOS/cnnrcgj 0122012.pdf>. Acesso em: 13 jun. 2017.

RIO GRANDE DO SUL. Décima Sétima Câmara Cível, Tribunal de Justiça, Apelação Cível № 70069606333. Relator: Giovanni Conti, Julgado em 30/06/2016). Disponível em: <http://www1.

tjrs.jus.br/sitephp/consulta/consulta_processo.php?

nome_comarca=Tribunal+de+Justi\%E7a\&versao $=\& v e r s a o \_f o n e t i c a=1 \&$ tipo $=1 \&$ id_comarca $=700 \&$ num_processo_mask $=70069606333 \&$ num_processo $=70069$ 606333\&codEmenta=6841819\&temIntTeor=true >. Acesso em: 01 jul. 2017.

RIO GRANDE DO SUL. Ministério Público. Preâmbulo do Provimento nº 21/2011 da CGJ/RS. Disponível em:

<http://www.mprs.mp.br/urbanistico/legislacao/id5904. htm>. Acesso em: 13 jun. 2017. 
RIZZARDO, Arnaldo. Direito das Coisas: Lei no 10.406, de 10.01.2002. Rio de Janeiro: Forense, 2011).

SALLES, José Carlos de Moraes. Usucapião de bens imóveis e móveis. São Paulo: Revista dos Tribunais, 2010.

STIFELMAN, Anelise Grehs; GARCEZ, Rochelle Jelinek. Do parcelamento do solo com fins urbanos em zona rural e da aplicação da lei no 6.766/79 e do provimento no 28/04 da CGJ/RS (Projeto More Legal). P. 01, 01-19. Artigo Científico. Disponível em: <www.mprs.mp.br/areas/urbanistico/arquivos/ parcelamento.doc>. Acesso em: 13 jun. 2017.

WOLF, Guilherme Eidelwein. A regularização fundiária urbana no Brasil e seus instrumentos de alcance. Notas introdutórias acerca do direito fundamental à moradia frente às políticas públicas de regularização fundiária. P. 19 de 86. Disponível em: <http:// www.jurisway.org.br/v2/dhall.asp?id_dh=8957>. Acesso em: 10 jun. 2017. 